\title{
PREVENTION OF COVID-19 TRANSMISSION IN ISLAMIC BOARDING SCHOOLS (PESANTREN): LITERATURE REVIEW
}

\author{
Ummi Malikal Balqis ${ }^{1 *}$, Obar $^{2}$, Sri Hartati ${ }^{3}$, Sifa Fauziah ${ }^{4}$, Papat Patimah ${ }^{5}$, Ricko Dwi Haryanto ${ }^{6}$, \\ Shinta Arini Ayu ${ }^{7}$ \\ 1. Department of Nursing, STIKes Permata Nusantara, Cianjur-Indonesia. \\ 2. Department of Nursing, STIKes Permata Nusantara, Cianjur-Indonesia. \\ 3. Department of Nursing, STIKes Permata Nusantara, Cianjur-Indonesia. \\ 4. Department of Nursing, STIKes Permata Nusantara, Cianjur-Indonesia. \\ 5. Department of Nursing, STIKes Permata Nusantara, Cianjur-Indonesia. \\ 6. Department of Nursing, STIKes Permata Nusantara, Cianjur-Indonesia. \\ 7. Department of Nursing, STIKes Permata Nusantara, Cianjur-Indonesia.
}

*Correspondence: Ummi Malikal Balqis | STIKes Permata Nusantara| ummimalikalbalqis@ gmail.com

\begin{abstract}
Introduction: COVID-19 is a disease caused by the SARS Cov 2 type corona virus with human-to-human transmission that causes respiratory tract infections, ranging from the common cold to serious diseases such as Middle East Respiratory Syndrome (MERS) and Severe Acute Respiratory Syndrome (SARS). Covid-19 has been designated as a global pandemic with a high risk of transmission in densely populated areas, one of which is Islamic Boarding Schools (Pesantren). The high social interaction of students in Islamic Boarding Schools causes students to be in a group at risk of being exposed to the corona virus. The purpose of this study is to find out the prevention of the transmission of Covid-19 in the Islamic Boarding Schools environment.

Method: The writing methodology used is a literature review using various articles from Google Scholar, ScienceDirect, and ProQuest according to the inclusion and exclusion criteria of the journal that have been determined.

Results: The results of this study are that Islamic boarding schools have attempted to prevent the transmission of Covid-19, including conducting health education related to preventing the transmission of Covid-19, providing hand washing facilities, conducting Tracing-Testing-Therapy (3T) for students with indications of Covid-19, providing self-isolation facilities, and implementing strict health protocols for all Islamic Boarding Schools residents.

Conclusion: This research shows that Islamic boarding schools have attempted to prevent the transmission of Covid19. The results of this study are expected to be a reference for related institutions to improve the quality of preventing the transmission of Covid-19 in the Islamic Boarding Schools environment.
\end{abstract}

Keywords: Covid-19; Pesantren; Preventions; Students; Transmition

Received October 21, 2021; Accepted December 30, 2021

\section{INTRODUCTION}

COVID-19 is a disease caused by the SARS Cov 2 type corona virus with human-to-human transmission that causes respiratory tract infections, ranging from the common cold to serious diseases such as Middle East Respiratory Syndrome (MERS) and Severe Acute Respiratory Syndrome (SARS) (Kementerian Kesehatan Republik Indonesia, 2020). The high rate of spread of this virus has caused WHO to declare COVID-19 as a world pandemic and urge all countries to increase efforts to prevent and manage COVID-19. The number of confirmed COVID-19 cases in Indonesia until November 2021 is 4.26 million, while the number of positive cases in the world is 262 million. The high number of confirmed cases of covid 19 in Indonesia causes Indonesia to rank 14th as the country with the most confirmed cases of covid 19 (Satuan Tugas Penanganan Covid 19, 2021b).

One of the age groups that the government focuses on is school-age children. School-age children are the nation's golden assets that must be protected from COVID-19 as future generations. On June 24, 2020 there were 250 thousand cases (12.6\%) from the child age group. The largest proportion is in the age group 7-12 years $(28.02 \%)$, the age group 16-18 years $(25.23 \%)$, and $13-15$ years $(19.92 \%)$ (Satuan Tugas Penanganan Covid 19, 2021a). In children, the risk of transmission comes from the immediate environment, such as boarding school like pesantren or islamic boarding school. Pesantren is a community-based Islamic religious education institution, both as an educational unit and/or as a forum for education provider 
(Kemenkes RI, 2013). Until 2020, there are 28,194 Islamic boarding schools throughout Indonesia with around 5 million students living in there (Nurhidayat et al., 2020). The long-term prediction of the COVID19 pandemic has caused all educational institutions (including Islamic boarding schools) in Indonesia have to innovate in their teaching and learning activities to prevent the transmission of COVID-19, especially in order to prepare the face-to-face learning process that will be carried out during this pandemic.

Life in Islamic boarding schools is very vulnerable to Covid-19 transmission due to the large number of students living together in one location. If one person suffers from Covid-19, the transmission will be very fast (Nurwayuni, 2021). The latest COVID-19 case finding in the pesantren environment was found in February 2021 in one of the Islamic boarding schools in West Java with a total of 380 pesantren residents who tested positive for COVID-19 (CNN Indonesia, 2021). The many positive cases are an illustration that the transmission of covid 19 in the pesantren environment can occur massively. Based on this, the author is interested in seeing further efforts to prevent the transmission of covid 19 in Pesantren through literature review studies in several related journals.

\section{METHOD}

Researchers used a literature review study to find the most appropriate methods in preventing the transmission of covid 19 in the pesantren environment based on the results of previous research. A literature review establishes familiarity with and understanding of current research in a particular field before carrying out a new investigation (Ramdhani et al., 2014).This literature review study has some criterias that must be haved by choosen journals. The inclussion criterias are journals contains preventing the "transmission of covid 19" in "schools", "boarding schools", or "Islamic boarding schools"; published nationally or internationally in 2019-2021; and from Google Scholar, ScienceDirect, and ProQuest. The exclussion criterias for the journals are Abstract journals, did not use English or Indonesian, and journals that were not displayed in full text.

\section{RESULTS}

Based on the search results, 23 journals were found which were considered to be in accordance with the research objectives. Then the author does a screening whether the titles in the journals have similarities. After screening, 10 articles with the same title were obtained. These ten journals are then screened based on eligibility according to inclusion and exclusion criteria. The results of the eligibility screening process stated that these 10 journals met the criteria in this literature review study. Henceforth, the 10 selected journals were reviewed in depth. The strategy for the literature search can be seen in the following table:

\begin{tabular}{cccc}
\hline Search Engine & Science-direct & ProQuest & Google Schoolar \\
\hline Result & 23 & 20 & 30 \\
Fulltext, Pdf, 2019-2021 & 20 & 20 & 30 \\
$\begin{array}{c}\text { Appropriate Tittle } \\
\text { Eligiblef according to the inclusion and } \\
\text { exclusion criteria }\end{array}$ & 2 & 3 & 17 \\
\hline
\end{tabular}

Research that meets the inclusion criteria has been carried out in various countries, including Indonesia, USA, and UK. The analysis of 10 selected journals shows that 4 journals use qualitative research methods, 1 journal uses prospective observational study, 1 journal uses quasi-experimental study, 1 journal uses cross sectional study, 1 journal uses literature review study, and 2 journals uses community empowerment study. After assessing the quality of the study, the ten journals can be categorized as good articles (high). Furthermore, the authors perform data extraction on 10 selected journals. Data extraction is done by analyzing and grouping important data based on the author's name, year, title, research method, and the results obtained. The extracted data can be seen in table 2 .

\begin{tabular}{lllll}
\hline No & Tittle & Writers & Method & Outcomes \\
\hline
\end{tabular}




\begin{tabular}{|c|c|c|c|}
\hline \begin{tabular}{|l|} 
No \\
\end{tabular} & Tittle & Writers & Method \\
\hline 1 & $\begin{array}{l}\text { Screening Students and } \\
\text { Staff for Asymptomatic } \\
\text { COVID-19 in Chicago } \\
\text { Schools }\end{array}$ & $\begin{array}{l}\text { (Edward et al. } \\
\text { 2021) }\end{array}$ & $\begin{array}{l}\text { Prospective } \\
\text { observational study } \\
(468 \text { participants } \\
\text { were tested: } 346 \\
\text { students and } 122 \\
\text { staff members) }\end{array}$ \\
\hline 2 & $\begin{array}{l}\text { Effectiveness } \\
\text { isolation policies in } \\
\text { schools: evidence from } \\
\text { a mathematical model of } \\
\text { influenza and COVID- } \\
19\end{array}$ & $\begin{array}{l}\text { (Burns \& } \\
\text { Gutfraind, } \\
\text { 2021) }\end{array}$ & $\begin{array}{l}\text { Quasy Experiment } \\
\text { with mathematical } \\
\text { model }\end{array}$ \\
\hline 3 & $\begin{array}{l}\text { COVID-19 in schools: } \\
\text { Mitigating classroom } \\
\text { clusters in the context of } \\
\text { variable transmission }\end{array}$ & $\begin{array}{l}\text { (Tupper \& \& } \\
\text { Colijn, 2021) }\end{array}$ & $\begin{array}{l}\text { Contrasting } \\
\text { Literature } \\
\text { crowdsourced data } \\
\text { available through } \\
\text { Covid r E'coles } \\
\text { Que'bec }\end{array}$ \\
\hline
\end{tabular}

Tuan Guru's role in social media to prevent

4 the spread of Covid-19 virus in west Nusa Tenggara, Indonesia

The new identity of Indonesian Islamic 5 boarding schools in the "new normal": the education leadership response to COVID-19

Minimizing the Spread of COVID 19 in Islamic

6 Boarding Schools, Schools and Puskesmas through the Assistance of Portable Sinks

Implementation of the Covid-19 Prevention and Handling Policy at 7 the Selamat Modern Islamic Boarding School, Kendal (Luth \& Qualitative (Najamuddin \& Qualitative method Suparto, 2021) with phenomenological approach

(Hanafi et al., 2021)

Qualitative Study

(Hayat et al., Community 2020) Empowerment 2021) Descriptive

Regency, Central Java

The Influence of Knowledge and

8 Personal Hygiene Behavior of Students on Covid-19 Prevention
The positive rate for all participants is 4.7\%. The results show that COVID-19 mitigation procedures, including masking and physical distancing, are effective in preventing the transmission of COVID-19 in schools.

Massive prevention of Covid-19 transmission can be done by reducing the duration of face-to-face learning. Faceto-face learning 3 times/week prevents transmission by $79-83 \%$, while face-toface learning 4 times/week prevents transmission by $52-64 \%$

Prevent transmission by preventing sick children from attending school, routinely screening for signs and symptoms of COVID-19, and avoiding activities in poorly ventilated environments.

Tuan Guru can explain to the public about the dangers of the COVID-19 virus and has a central role in influencing public perception in preventing COVID19 , including the MUI fatwa regarding the dangers of Covid 19 which affects the written and unwritten curriculum at Islamic boarding schools in West Nusa Tenggara

Pesantren leaders have shown good practice in making decisions related to protecting teachers and students from the dangers of COVID-19. They have even prepared the pesantren to face school closures for the second time if there is an increase in positive cases of COVID-19.

The way to prevent the transmission of COVID-19 in Islamic boarding schools is to always wash hands with soap and running water. The provision of portable hand washing equipment in the pesantren environment is considered effective enough to prevent the transmission of covid 19 in the pesantren environment The Covid-19 transmission prevention policies implemented at Pesantren Selamat include health promotion activities, providing health protocol support facilities, case finding, providing self-isolation facilities, providing health service facilities, and closing access to boarding schools

Knowledge of covid 19 and hygienic behavior do not really affect the transmission of covid 19. Prevention of covid 19 transmission in Islamic boarding schools is more influenced by 
Jurnal Mitra Kesehatan (JMK)

DOI: $10.47522 /$ jmk.v1iIAHSC.107

ISSN: 2580-3379 (print); 2716-0874 (online)

\begin{tabular}{|c|c|c|c|c|}
\hline No & Tittle & Writers & Method & Outcomes \\
\hline & $\begin{array}{l}\text { and Transmission at } \\
\text { New Normal Era in } \\
\text { Islamic Boarding School } \\
\text { of Malang City }\end{array}$ & & & $\begin{array}{l}\text { other factors such as motivation, } \\
\text { attitudes, and behavior in preventing } \\
\text { COVID-19. }\end{array}$ \\
\hline 9 & $\begin{array}{l}\text { Management of Islamic } \\
\text { Boarding Schools } \\
\text { during the COVID-19 } \\
\text { pandemic (Study of } \\
\text { Mambaul Ulum Islamic } \\
\text { Boarding } \\
\begin{array}{l}\text { Kedungadem School } \\
\text { Bojonegoro) }\end{array}\end{array}$ & $\begin{array}{l}\text { (Kahfi } \quad \& \\
\text { Kasanova, } \\
\text { 2020) }\end{array}$ & $\begin{array}{l}\text { Qualitative } \\
\text { Descriptive }\end{array}$ & $\begin{array}{l}\text { Islamic boarding schools have attempted } \\
\text { to implement government policies with } \\
\text { various adaptations. However, Islamic } \\
\text { boarding schools do not yet have } \\
\text { standard standards for handling the } \\
\text { COVID-19 pandemic emergency } \\
\text { response in them, causing disruption to } \\
\text { the teaching and learning process, } \\
\text { institutional administration, and the } \\
\text { pesantren economy. }\end{array}$ \\
\hline 10 & $\begin{array}{l}\text { Improving knowledge, } \\
\text { attitudes, and practices } \\
\text { of COVID-19 reduction } \\
\text { through Santri Husada } \\
\text { Program }\end{array}$ & $\begin{array}{l}\text { (Khoirul et al., } \\
\text { 2021) }\end{array}$ & $\begin{array}{l}\text { Community } \\
\text { empowerment }\end{array}$ & $\begin{array}{l}\text { The results of this research show that } \\
\text { students knowledge, attitudes and } \\
\text { prevention practices COVID-19 showed } \\
\text { a good score with the correlation (R- } \\
\text { square: P-Value) knowledge- attitude } \\
\text { prevention of Covid } 19(0.167: 0.000) \text {, } \\
\text { knowledge-prevention practice covid } 19 \\
(0.060 \text { : 0.000) and attitude-prevention } \\
\text { practice covid } 19(0.051: 0.000) \text {. }\end{array}$ \\
\hline
\end{tabular}

\section{DISCUSSION}

Based on an analysis of 10 selected journals, it was found that boarding houses with the concept of pesantren can make various efforts to prevent the transmission of covid 19 in their environment. Efforts that can be made to prevent the transmission of covid 19 in the pesantren environment include conducting health education related to preventing the transmission of Covid-19, providing hand washing facilities, conducting Tracing-Testing-Therapy for students with indications of Covid-19, providing self-isolation facilities, and implementing strict health protocols for all pesantren residents.

The first effort to prevent the covid 19 transmission in Islamic boarding schools is conducting health education related to preventing the transmission of Covid 19. Three journals that support that health education to preventing covid 19 transmission are effective in preventing the transmission of covid 19 in Islamic boarding schools are delivered by Khoirul et al. (2021), Luth and Meriwijaya (2021), and Nurhidayat et al. (2020). Research conducted by Khoirul et al. (2021) on 93 pesantren residents through the Santri Husada Program, they were able to improve knowledge, attitudes, and practices of COVID-19 reduction in the pesantren environment. The results of this research show that students' knowledge, attitudes and prevention practices COVID-19 showed a good score with the correlation (R-square: P-Value) knowledge- attitude prevention of Covid 19 (0.167: 0.000), knowledge-prevention practice covid 19 (0.060: $0.000)$ and attitude-prevention practice covid 19 (0.051: 0.000). In addition to providing health education to prevent the transmission of Covid 19 directly to all residents of Islamic boarding schools, the implementation of policies to make the provision of health education to prevent transmission of Covid 19 as one of the policies to prevent transmission of Covid 19 in the pesantren environment is considered quite effective. This is supported by research conducted by Luth and Meriwijaya (2021) through a study of the policy on preventing the transmission of covid 19 at the Modern Selamat Islamic boarding school, Kendal Regency, Central Java. Luth and Meriwijaya (2021) stated that the policies that contain a health promotion about covid 19 are able to prevent the transmission of in the pesantren. The health promotion for preventing the spread of COVID-19 is carried out through the creation of health education banners placed in strategic places in the pesantren area so that all residents of the pesantren can easily read and understand it. Quite different from the results of the research above, Nurhidayat et al. (2020) stated that knowledge of covid 19 and hygienic behavior do not really affect the transmission, a motivation, attitudes, and behavior in preventing COVID-19 have a more effect. The results of this research can be used as a guideline that the first step to prevent the transmission of covid 19 in Islamic boarding schools is to provide health education 
about covid 19, starting from what Covid 19 is to what efforts can be made to prevent transmission in the pesantren environment.

Second effort to prevent the covid 19 transmission in Pesantren is providing hand washing facilities. Two journals that support providing hand washing facilities to preventing covid 19 transmission are effective in preventing the transmission of covid 19 in Islamic boarding schools, presented by Hayat et al. (2020) and Luth and Meriwijaya (2021). Through community empowerment conducted by Hayat et al. (2020), data obtained that one of the ways to prevent the transmission of COVID-19 in Islamic boarding schools is to always wash hands with soap and running water. The provision of portable hand washing equipment in the pesantren environment is considered effective enough to prevent the transmission of covid 19 in the pesantren environment. The habit of washing hands can also be applied as one of the pesantren policies to prevent the transmission of COVID-19 in their environment. The implementation of the hand washing policy as an effort to prevent the transmission of covid 19 in the pesantren environment was conveyed by Luth and Meriwijaya (2021) through a descriptive qualitative research methodology at Islamic boarding schools in Central Java. In the results of the research, it is stated that providing health protocol facilities such as hand washing facilities for students at pesantren can prevent the transmission. In line with these results, Dwipayanti et al. (2021) also stated that washing hands with running water and soap is considered effective in preventing the transmission of COVID-19 with an OR value of 1.77, 1.232.54. Thus, the provision of hand washing facilities in the pesantren environment to prevent the transmission of covid 19 is one of the effective efforts to build a clean and healthy lifestyle as an effort to prevent the transmission of covid 19 in the pesantren environment.

Third effort to prevent the covid 19 transmission in Pesantren is conducting Tracing-Testing-Therapy for students with covid 19 Indications. Three journals that support efforts to prevent the spread of COVID19 through conducting Tracing-Testing-Therapy for students with Indications of Covid 19 in Islamic boarding schools were presented by Tupper and Colijn (2021), Luth and Meriwijaya (2021), and Edward et al. (2021). Edward et al. (2021) and Tupper and Colijn (2021) specifically discussed preventing the transmission of covid 19 in the school environment. School is one of the main activities in pesantren. Control and prevention of COVID-19 transmission in schools as part of the pesantren environment is also one of the effective efforts to prevent the wider transmission of COVID-19. Edward et al. (2021) through a prospective observational study of 468 participants in the school environment stated that testing of symptomatic cases combined with contact tracing reduces transmission in school with a positive rate of 4.7\% from January-March 2021. Another study was submitted by Tupper and Colijn (2021) through the Contrasting Literature study on crowdsourced data available through Covid E'coles Que bec stated that testing a symptomatic individual in school is able to prevent large transmission clusters. Tupper and Colijn (2021) also mentioned that routinely screening for signs and symptoms of covid 19 and preventing sick children from going to school can prevent transmission of covid in the school environment. Specifically, Luth and Meriwijaya (2021) stated that the implementation of the Tracing-Testing-Therapy of covid 19 in the pesantren environment was carried out by coordinating with the Public Health Center (Puskesmas) in accordance with guidelines from the ministry of health. The collaboration between pesantren and the nearest puskesmas according to their target area through Poskestren (Pos Kesehatan Pesantren) activities will facilitate the monitoring, control, and handling of covid 19 in pesantren. The success of pesantren in carrying out Tracing-Testing-Therapy will make a significant contribution in efforts to improve the health status of the pesantren community during the COVID-19 pandemic.

Next effort to prevent the covid 19 transmission in Pesantren is providing self-isolation facilities. Two journals that support providing self-isolation facilities are presented by Hanafi et al. (2021) and Luth and Meriwijaya (2021). Through a descriptive qualitative study on the handling of covid 19 in Islamic boarding schools in Central Java, Luth and Meriwijaya (2021) stated that the provision of self-isolation facilities carried out in Islamic boarding schools based on guidelines from the ministry of health can prevent the transmission of Covid 19 in Islamic boarding schools. The criteria of pesantren residents who must be in self isolation facilities including pesantren residents who have close contact with COVID-19 survivors, travel history to red zone areas (including students who have just returned to pesantren after returning home), and have typical symptoms which leads to covid 19. The making of self isolation facilities in this pesantren is one of the policies at the boarding school. These self-isolation facilities are integrated with the handling of COVID-19 at the local Puskesmas. Another study submitted by Hanafi et 
al. (2021) in a qualitative study using Focus Group Discussion stated that to prevent cases of COVID-19 infection, Pesantrean Staffs check the temperature of students and teachers at least twice a day, require students to quarantine for 14 days before entering Islamic boarding schools and carry out rapid tests to detect COVID-19 early. This is in line with the results of research presented by Nam et al. (2021) which states that self-isolation is represented as a core intervention in significantly disrupting the pandemic's spread. From the various research results above, the establishment of self-isolation facilities for pesantren residents with indications of covid 19 and a history of travel outside the pesantren area can be an effective effort to prevent the transmission of covid 19 in the pesantren area.

Last effort to prevent the covid 19 transmission in Pesantren is implementing strict health protocols for all pesantren residents. Strict health protocols are defined as 3M's efforts (Using masks, Washing hands, and Social distancing). Five journals that support implementing strict health protocols for all pesantren residents effectively prevent the transmission of covid 19 in Islamic boarding schools are submitted by Kahfi and Kasanova (2020), Burns and Gutfraind (2021), Luth and Meriwijaya (2021), Hanafi et al. (2021) and Najamuddin and Suparto (2021). Through a qualitative descriptive study at Islamic boarding schools in East Java, Kahfi and Kasanova (2020) stated that implementing strict health protocols as recommended by the government can prevent the transmission of covid 19 in Islamic boarding schools. At the beginning of the COVID-19 pandemic in March 2020, the pesantren even stopped all face-to-face teaching and learning activities and repatriating all students. All teaching and learning activities are carried out online in accordance with government recommendations as an effort to prevent the spread of COVID-19. Efforts to implement strict health protocols with a massive prevention of Covid-19 transmission can be done by reducing the duration of face-to-face learning. Burns and Gutfraind (2021) through a quasi-experimental study stated that face-to-face learning 3 times/week prevents transmission by $79-83 \%$, while face-to-face learning 4 times/week prevents transmission by 52-64\%. The application of strict health protocols to prevent the transmission of COVID-19 in the pesantren environment can also be incorporated into the internal policies of the pesantren. Najamuddin and Suparto (2021) said that the explanation from Tuan Guru (Governor of West Nusa Tenggara) about the MUI (Indonesian Ulema Council) fatwa regarding the dangers of Covid 19 affects the written and unwritten curriculum and policies at Islamic boarding schools in West Nusa Tenggara so that the number The spread of COVID-19 in Islamic boarding schools in the province can be controlled. Luth and Meriwijaya (2021) and Hanafi et al. (2021) also mentioned that the application of strict health protocols in collaboration with local health centers as stated in the policies in Islamic boarding schools was able to reduce the spread of covid 19 in the pesantren environment. Based on the results of the research above, it shows that efforts to implement strict health protocols to prevent the transmission of covid 19 in the pesantren environment are an effective effort to prevent massive transmission in the pesantren environment.

\section{CONCLUSION}

This literature review show that Islamic boarding schools have attempted to prevent the transmission of Covid-19, including conducting health education related to preventing the transmission of Covid-19, providing hand washing facilities, conducting Tracing-Testing-Therapy for students with indications of Covid-19, providing self-isolation facilities, and implementing strict health protocols for all pesantren residents. The results of this study are expected to be a reference for related institutions to improve the quality of preventing the transmission of Covid-19 in the pesantren environment.

\section{REFERENCE}

Burns, A. a. C., \& Gutfraind, A. (2021). Effectiveness of isolation policies in schools: Evidence from a mathematical model of influenza and COVID-19. PeerJ, 9, 1-16. https://doi.org/10.7717/peerj.11211

CNN Indonesia. (2021). Positif Covid, 380 Orang di Ponpes Tasikmalaya Dievakuasi. https://www.cnnindonesia.com/nasional/20210216095614-20-606721/positif-covid-380-orang-diponpes-tasikmalaya-dievakuasi

Dwipayanti, N. M. U., Lubis, D. S., \& Harjana, N. P. A. (2021). Public Perception and Hand Hygiene Behavior During COVID-19 Pandemic in Indonesia. Frontiers in Public Health, 9(May), 1-12. https://doi.org/10.3389/fpubh.2021.621800 
Edward, P. R., Reyna, M. E., Daly, M. K., Hultquist, J. F., Muller, W. J., Ozer, E. a., Lorenzo-Redondo, R., Seed, P. C., Simons, L. M., Sheehan, K., Staples, J., \& Kociolek, L. (2021). Screening Students and Staff for Asymptomatic COVID-19 in Chicago Schools. The Journal of Pediatrics. https://doi.org/10.1016/j.jpeds.2021.08.017

Hanafi, Y., Taufiq, A., Saefi, M., Ikhsan, M. A., Diyana, T. N., Thoriquttyas, T., \& Anam, F. K. (2021). The new identity of Indonesian Islamic boarding schools in the "new normal": the education leadership response to COVID-19. Heliyon, 7(3). https://doi.org/10.1016/j.heliyon.2021.e06549

Hayat, A., Erwin, A., Arma, L. H., Arsyad, H., Syahid, M., Amaliyah, N., Duma, G. A., \& Sakka, A. (2020). Minimalisasi Penyebaran COVID 19 Pada Lingkungan Pesantren, Sekolah dan Puskesmas Melalui Bantuan Alat Wastafel Portabel. JURNAL TEPAT: Applied Technology Journal for Community Engagement and Services, 3(2), 65-72. https://doi.org/10.25042/jurnal_tepat.v3i2.139

Kahfi, S., \& Kasanova, R. (2020). Manajemen Pondok Pesantren Di Masa Pandemi Covid-19. Pendekar: Jurnal Pendidikan Berkarakter, 3(1), 26-30.

Kementerian Kesehatan Republik Indonesia. (2020). Pertanyaan dan Jawaban Terkait COVID-19 Kementerian Kesehatan. https://www.kemkes.go.id/article/view/20030400008/FAQCoronavirus.html

Khoirul, F., Ikhsan, M. A., Hanafi, Y., Adzim, A., \& Muzdalifah, Z. (2021). Improving knowledge , attitudes, and practices of COVID-19 reduction through Santri Husada Program. 2(2), 69-76.

Luth, L., \& Meriwijaya, M. (2021). Implementasi Kebijakan Pencegahan Dan Penanganan Covid-19 Di Pondok Pesantren Modern Selamat Kabupaten Kendal, Jawa Tengah. Kybernan: Jurnal Studi Kepemerintahan, 4(1), 90-109. https://doi.org/10.35326/kybernan.v4i1.1142

Najamuddin, A. M. Y., \& Suparto, W. (2021). Tuan Guru' s role in social media to prevent the spread of Covid-19 virus in west Nusa Tenggara, Indonesia. Utopia Y Praxis Latinoamericana, 26.

Nam, N. H., Tien, P. T. M., Van Truong, L., El-Ramly, T. A., Anh, P. G., Hien, N. T., Mahmoud, E. M., Eltaras, M. M., Khader, S. A. E., Desokey, M. S., Gayed, R. M., Alhady, S. T. M., Do Le, B. T., Nguyen, D. P. N., Tiwari, R., Eldoadoa, M., Howard, B., Trung, T. T., \& Huy, N. T. (2021). Early centralized isolation strategy for all confirmed cases of COVID-19 remains a core intervention to disrupt the pandemic spreading significantly. PLoS ONE, $16(7$ July), 1-17. https://doi.org/10.1371/journal.pone.0254012

Nurhidayat, L., Wicaksono, R. S., Mustika, S., Division, I. M., Brawijaya, U., Division, G., Brawijaya, U., Nurhidayat, L., Wicaksono, R. S., Mustika, S., Division, I. M., Brawijaya, U., Division, G., \& Brawijaya, U. (2020). Pengaruh Tingkat Pengetahuan Dan Perilaku Higiene Santri Terhadap. Pencegahan Dan Penularan Covid-19 Selama Masa New Normal di Pondok Pesantren Kota Malang. Jurnal Kedokteran Komunitas, 1-6.

Nurwayuni, A. (2021). Edukasi Santri Di Pondok Pesantren, Upaya Cegah Covid-19 Universitas Indonesia. https://www.ui.ac.id/edukasi-santri-di-pondok-pesantren-upaya-cegah-covid-19/

Ramdhani, A., Ramdhani, M. A., \& Amin, A. S. (2014). Writing a Literature Review Research Paper: A step by step approach. International Journal of Basics an Applied Sciences, 03(1), 47-56. https://doi.org/10.1177/0021886391273004

Satuan Tugas Penanganan Covid 19. (2021a). Lindungi Anak dan Remaja Kita dari Varian Baru Covid-19. https://promkes.kemkes.go.id/lindungi-anak-dan-remaja-kita-dari-varian-baru-covid-19

Satuan Tugas Penanganan Covid 19. (2021b). Peta Sebaran Covid 19. https://covid19.go.id/peta-sebaran

Tupper, P., \& Colijn, C. (2021). COVID-19 in schools: Mitigating classroom clusters in the context of variable transmission. PLoS Computational Biology, 17(7), 1-21. https://doi.org/10.1371/journal.pcbi.1009120 